\title{
JONATHAN EDWARDS' EMPHASIS ON RELIGIOUS AFFECTIONS AS VIA MEDIA TO EXTREME RESPONSES OF REVIVAL
}

\author{
Heruarto Salim \\ Gereja Reformed Injili Indonesia Kemayoran Jakarta
}

\begin{abstract}
God's great work to reform His churches on earth many times preceded by great revival sent by Him. Apparently many revival like the one in the Great Awakening of New England colony in the eighteenth century produced two opposing responses: either fanaticism or denial. The Great Awakening became a battle to answer a key question: whether the Great Awakening was a genuine work of the Spirit? What is a true revival, then according to Reformed theology? The figure most fit to answer this question is none other than Jonathan Edwards. In the midst of the controversy, Jonathan Edwards stood in the middle ground trying to justify that the Great Awakening was truly a work of God while at the same time critical towards the excesses. Edwards Treatise of Religious Affections will be related to his discussion on the centrality of affections in religion, the nature of experience and the assurance of salvation.
\end{abstract}

KEYWORDS: Jonathan Edwards, Revival, Great Awakening, Religious Affections, George Whitefield, Charles Chauncy.

ABSTRAK: Pekerjaan Tuhan untuk mereformasi gereja-Nya seringkali diawali dengan kebangunan rohani. Namun banyak kebangunan rohani mengalami nasib seperti the Great Awakening di koloni New England di abad kedelapan-belas yang terpecah menjadi dua kubu: yang fanatik mendukung atau yang menolak. The Great Awakening menjadi pertarungan untuk menjawab satu pertanyaan kunci: apakah The Great Awakening memang 
merupakan pekerjaan Roh Kudus? Apakah yang dimaksud dengan kebangunan sejati menurut teologi Reformed? Tokoh yang paling cocok menjawab pertanyaan ini adalah Jonathan Edwards. Di tengah-tengah kontroversi tersebut, Edwards mempertahankan posisi tengah yaitu meyakinkan bahwa the Great Awakening merupakan pekerjaan Tuhan namun sekaligus bersikap kritis terhadap penyimpangan-penyimpangan yang terjadi. Karya Edwards Treatise of Religious Affection akan dikaitkan dengan diskusinya tentang sentralitas afeksi dalam agama, natur dari pengalaman dan juga jaminan keselamatan.

KATA KUNCI: Jonathan Edwards, kebangunan, Great Awakening, pengalaman rohani sejati, George Whitefield, Charles Chauncy.

Revival is a very important matter. An urgent matter as well. Dr. Martin Lloyd-Jones, a minister of Westminster Chapel in London for 25 years and recognised as one of this century's most gifted preacher and writer, stated his most longing desire of his heart to the people of his time "I am calling your attention ... to the urgent need, of a revival in the Church of God at the present time for I am persuaded that this is a very urgent matter."1 Indeed his concern were shared by many as we can see from the number of books published on the subject of revival. An annotated bibliography on revival boasts a staggering number close to 6,000 titles! ${ }^{2}$ "The main reason we should be praying about revival is that we are anxious to see God's name vindicated and his glory manifested", Lloyd-Jones answers. Furthermore, he continues, revival is about "the glory of God, the power, and the name and the honour of God."3

\footnotetext{
Martyn Lloyd-Jones, Revival (Westchester: Crossway, 1987), 7.

2 Richard Owen Roberts, Revival Literature, an Annotated Bibliography with Biographical and Historical Notices (Wheaton: Roberts, 1987), x.

3 Lloyd-Jones, Revival, 120.
} 
It is natural to choose Jonathan Edwards if we want to understand about revival, because "he was a mighty theologian and a great evangelist at the same time... He was pre-eminantly the theologian of revival." ${ }^{4}$ J.I. Packer sounded the same when he wrote "Of all theological writers on the reviving of religion, I hail Jonathan Edwards as not only the first but also the best." 5 The reason Edwards such an authoritative figure on the theme of revival is that he himself oversaw awakening within his own church in Northampton in 1734-35, greatly involved in the Great Awakening in 174041 , promoted revivals on international scale, wrote extensive publication on the subjects that were still widely read until now. This very reason contributes to why "more than three centuries after his birth, Edwards has continued to be cited as an authority on revival and might be regarded as the most influential author of all time on this theme." 6

Jonathan Edwards (1703-1758) is regarded as colonial America's greatest theologian and philosopher. During his fruitful life, he served as a teacher, pastor, revivalist, missionary and college president. ${ }^{7}$ Jonathan Edwards was born October 5, 1703 in East Windsor, Connecticut. His context in a colonial America in the beginning of eighteenth century was in a turning period from a period much influenced by strong puritan heritage brought by the first American Puritan settlements to a period influenced by European Enlightenment era. From the 1660 until 1740s, the New England elite frequently expressed a perception of spiritual decline and a desire for spiritual revitalisation in the colonies. ${ }^{8}$

\footnotetext{
4 Lloyd-Jones, The Puritans: Their Origins and Successors. (Edinburgh Lothian: Banner of Truth Trust, 1987), 361.

5 John Piper and Justin Taylor, A God Entranced Vision of All Things, (Wheaton: Crossway, 2004), 105.

6 Michael James McClymond and Gerald R. McDermott, The Theology of Jonathan Edwards (New York: Oxford University Press, 2012), 424.

7 Jonathan Edwards, A Jonathan Edwards Reader, ed. John E. Smith, Harry S. Stout, and Kenneth P. Minkema (New Haven: Yale University Press, 1995), vii.

8 Ibid.
} 
The desire for that spiritual revitalisation were granted by God when a substantial earthquake shook New England in October 29, 1727. Edwards, who was at that time under the tutelage of his grandfather, Solomon Stoddard did not miss the chance to remind the people that the earthquake was not a mere catastrophe but a divine sign for them to repent of their sins.But this revival did not last long. In April 1734 came a dramatic turning point. A sudden death of a young man helped sparked the fire of revival, which had been waited by Edwards all along. Edwards again grabbed the opportunity. In his public preaching on that occasion he reminded the shaken young people there of how fleeting life was and challenged them to depart from their old ways.

When Edwards recounted God's very extraordinary dispensation of providence happened in Northampton, his judgment was that God had gone out of his usual and ordinary way in many respects. It was remarkable in the universality of it: affecting all strata of social structure, both rich and poor, both educated and uneducated; in the numbers of people affected: three hundred people converted; in the regenerating influences to all ages: both to the elderly and the the very young children; and lastly in the swiftness, degrees and extent of the Spirit's work. ${ }^{9}$ Northampton's revival fervour was contagious. Edwards believed God used awakening in Northampton to influence other towns as it was reported "Nearly thirty communities up and down the Connecticut River Valley attesting to the revival spirit in their churches." 10

Edwards reply to a simple request by a Boston minister, Benjamin Colman in 1735 to describe an account of the late phenomena, unknown to anybody but God, would turn out to be the first revival account published

\footnotetext{
9 Jonathan Edwards, Jonathan Edwards On Revival (Edinburgh: Banner of Truth Trust, 1984), 19.

10 Harry Stout,"Edwards as Revivalist," Cambridge Companion to Jonathan Edwards (Cambridge: Cambridge University Press, 2007), 125.
} 
on a large scale. His writing would be called A Faithful Narrative of the Surprising Work of God in the Conversion of Many Hundred Souls in Northampton (A Faithful Narrative). Edwards A Faithful Narrative was a favoured popular, contemporary narrative used in validating, shaping, and defending the revival as it progressed.11 It also served to fuel up people's expectation and hope that the same awakening would also happened in their land.

Noll rightly evaluates that Edwards A Faithful Narrative "exerted a much broader influence than the sermons Edwards had preached during the revival itself." 12 He closes with, "it was Edwards narrative of revival more than the theology he himself presented as its foundation that most fired the evangelical imagination." 13 However much Edwards long to have this revival to last, it ends just as swiftly as it had begun.

In God's providential timing, its publication in England "coincided with revivals in Wales and England between 1737 and 1739. Revival news across the Atlantic was reciprocal.14 Publication of A Faithful Narrative by Isaac Watts and John Guyse in London has inspired British revivalists. Edwards and the New England revivalist also received news of extraordinary development from London that in late 1737, God also poured out His Spirit mightily there. George Whitefield took his revival over much of the southern half of England and Wales in the late 1730s, attracting enormous crowds and widespread publicity that reached as far as the American colonies. ${ }^{15}$

\footnotetext{
11 Robert Davis Smart, Jonathan Edwards's Apologetic for the Great Awakening (Grand Rapids: Reformation Heritage Books, 2011), 16.

12 Mark A. Noll, The Rise of Evangelicalism: the Age of Edwards, Whitefield, and the Wesleys (Downers Grove: InterVarsity Press, 2003), 90.

13 Ibid., 91.

14 Frank Lambert, Inventing The "Great Awakening" (Princeton: Princeton University Press, 1999), 87.

15 Ibid.
} 
Whitefield's visit to New England brought a new character to the colonies. No longer were revivals local, isolated awakenings; they become linked into a single movement. ${ }^{16}$ Spread by the powerful preaching of George Whitefield - the "grand itinerant" - and by scores of other preachers throughout the American colonies, the Great Awakening converted perhaps as much as $15 \%$ of the total population of the American Colonies in a single year (1740). ${ }^{17}$ Aside from number of converts, it also revitalised old congregations; spurred the establishment of colleges such as Brown, Princeton, and Rutgers; and brought new hope to those for whom the old Puritan vision had begun to fade. ${ }^{18}$

Edwards discovered that nothing would promote revival better than the haunting spectre of "infinite punishment."19 Because of this conviction, he did not feel uneasy to speak the horrors of hell, as long as it did not become an end in itself but as means to gain converted souls. In history, the shift were eternally imprinted on his legacy of hell-brimming preacher when he were invited to preach in Enfield on July 8, 1741. There, he preached "Sinners in the Hands of an Angry God". Edwards, unfortunately, would be forever known and characterized by this sermon. Sinners in the Hands of an Angry God is arguably America's greatest sermon..$^{20}$

\section{The Rise of the Radical New Lights}

In the early stages of Awakening in 1740, the zeal and excitement brought by the Awakening was so high that virtually no one openly dared to question or critize it. Because of the strong support of the awakening in its

\footnotetext{
16 Ibid., 92.

17 Gary Stratton, "Review of Edwards, Jonathan. A treatise concerning religious affections," Christian Education Journal, 3d ser. 3 no. 1 (Spring 2006): 200-206.

18 Garth Rosell, The Surprising Work of God: Harold John Ockenga, Billy Graham, and the Rebirth of Evangelicalism (Grand Rapids: Baker, 2008), 35.

19 Stout, Edwards as Revivalist, 134.

20 Stout, Edwards as Revivalist, 140.
} 
early stages, "most ministers embraced the revival as the sought-after outpouring the Spirit."21 Thus before 1742 there was no definitive radical New Light Group, and criticism from Old Lights remained anonymous.

The main problem with the Radicals was that they interpreted the Awakening as a true work of the Spirit with an "either-or" logic. Either you have "all of the Spirit" or "none of the Spirit", which later resulted in many excesses. It embolden them, for example, to encourage people to leave their congregation should their ministers did not endorse the Radicals' cause, and presumed to know the spiritual state of ministers and accusing them as unregenerate. ${ }^{22}$ This can be seen for example in the case of James Davenport, certainly the most well known among the radical New Lights.

Marsden analyzed, "for the next several years much of Edwards energy would be devoted to what amounted to a verbal duel with a Boston Pastor Charles Chauncy, the most outspoken champion of the Old lights."23 The divide cannot be prevented, "New England's clerical establishment would be permanently divided between 'New Light' awakeners and 'Old Light' critics." 24

Among the Radicals, it was James Davenport more than any other minister, who embodied everything that was wrong with the Awakening. He was notoriously known for his raucous revival meeting accompanied by wild gestures. This he did by his anticlerical action - declaring ministers unconverted and encouraged ecclesiastical separation at virtually every itinerant stop he made.

21 Smart, Jonathan Edwards's Apologetic, 50.

22 Ibid., 51.

23 George M. Marsden, Jonathan Edwards: A Life (New Haven: Yale University Press, 2003), 238.

24 Ibid. 


\section{The Rise of the Opponent Old Lights}

In the early stages of Awakening very little resistance directed to the Awakening. Later on Chauncy became more emboldened and more decided in his opposition. He did not believe Whitefield really brought great good, for the town was not better off. Not only that, he would even thought the town were getting worse, "There never was such a spirit of superstition and enthusiasm reigning in the land before." He gave his final answer, "The goodness that has been so much talked of is nothing more, in general, than a commotion in the passions." ${ }^{25}$ Edwards and the New Lights ministers were still holding the trump cards, enjoying wide reception. However, the New Lights radical side also grew emboldened in their insistence of the bodily effects, enthusiasm and censorious message.

Davenport fanaticism did gave the opponents a big advantage, offering the Old Light critics more than enough evidence to both moderately and radically oppose him. Chauncy, initially launched his attack anonymously, could now speak his mind openly since Davenport's visit had thrown the friends of revival into such disarray. Bitterness, evil speaking, slander, and lay exhorters showing contempt for pastors were not God's work. Sensationalists were betraying people by overheating their imaginations and calling the result true religion. ${ }^{26}$

By the time Edwards published his Some Thoughts trying to defend the cause of revival, the imprudence and irregularities had gained strength considerably and more numerously by Radicals, something which Edwards may never have expected before. Edwards knew by taking a middle ground, he had to engage a two-pronged battle against both the radical New Light side and the decided and emboldened opposers Old Light. However, just within a few years, the battle was completely overturned in 1744 . The Great

25 Marsden, Jonathan Edwards: A Life, 238.

26 Ibid., 271. 
Awakening had to come to an end. Great Awakening, like the Little Awakening of Northampton would once again disappoint Edwards. Ruefully, he recognized that unrelented terror could not work indefinitely, nor would his parishioners respond with the "affections" he demanded. ${ }^{27}$

\section{The Tendencies of The Two Extreme Responses}

The main underlying question in the centre of the controversy was this: whether the Great Awakening was a work of the Holy Spirit or not? Many players in the controversy gave different answer and qualifications. To answer with a simple yes or no is an immense oversimplification. "Various are the sentiments of persons about this unusual appearance among us," writes Chauncy, dividing his contemporaries into four grouping:

1. Some think it is a most wonderful work of God's Grace;

2. others a most wonderful spirit of enthusiasm;

3. some think there is a great deal of Religion, with some small Mixture of Extravagances;

4. others, a great deal of extravagance with some small mixture of that which may be called good 28

Chauncy's category helps to break away from two opposite extremes: There was not a bit of the Spirit's work involved in the Great Awakening or it was totally a work of the Spirit including all the extravagances.

\section{The Dangerous Tendencies of the Radical New Lights}

If all the objections towards the traits of the Radical New Lights can be found in one work or publication, it was certainly in Chauncy's Seasonable Thoughts. That systematic and comprehensive coverage was done by

27 Stout, Edwards as Revivalist, 141.

28 Smart, Jonathan Edwards's Apologetic, 50. 
Chauncy's travelling three hundred miles to collect evidences on a threemonth tour. Smart comments, "in one sense, it was an anthology of all the anti-revival literature from the period crammed into one volume." 29

In the first part, he listed down eight "things of a bad and dangerous tendency" which "instead of being the genuine fruits of a work of God, are real hindrances to the flourishing of pure and undefiled religion" 30 Those eight were itinerant preaching, terror, sudden light and joy, rash censorious and uncharitable judging, impulses and impressions, exhorters, confusion in houses of worship, and the prevalent spirit of error. ${ }^{31}$

\section{Antinomianism $^{32}$}

If all eight and bad and dangerous tendencies, all of the objections, criticisms and accusations raised by the Old Lights towards the New Lights to be condensed into just two accusations, those two would be: Antinominanism and enthusiasm. This can be further adduced from Ava Chamberlain's quotation when he wrote of Edwards trying to vindicate himself and the Awakening, "it became necessary for Edwards both to address the rationalist critique and to differentiate experimental religion from the Antinomianism and enthusiasm of the radical New Lights." 33

The reason the New Lights were charged with Antinomianism was they were seen subverting the Puritans doctrine and also the New England cultural norm. Antinomianism charges itself carried a critical past historical baggage. It was a serious charges indeed. The first Antinomianism crisis

29 Smart, Jonathan Edwards's Apologetic, 180.

30 Charles Chauncy, Seasonable Thoughts On Religion in New England (Boston: Printed by Rogers and Fowle for Samuel Eliot, 1743; Hicksville: Regina Press, 1975), 34.

31 Smart, Jonathan Edwards's Apologetic, 197.

32 Antinomian literally meant "anti-law"; in theological terms, it referred to one who elevated internal, subjective experience of the Spirit over outward, objective obedience to the moral law. Definition taken from Smart, 182.

33 Ava Chamberlain, "Self-Deception as a Theological Problem in Jonathan Edwards's 'Treatise Concerning Religious Affection.'” Church History 63, no. 4 (December 1994): 542. 
occurred in 1630s in New England when Anne Marbury Hutchinson expressed her opinion which disconnected justification and sanctification. She came to a conclusion herself that good works and sanctification were not deemed essential. Before the trial in November 1638, Hutchinson unanimously excommunicated from Boston's First Church. She and her group were banished from the Massachusetts Bay Colony and five years later, she died in Long Island. ${ }^{34}$ In his Seasonable Thoughts, Chauncy argued throughout that "both the Antinomian and the awakened abandoned outward signs of sanctification for a new practice of judging men's heart based upon a sudden visitation of the Spirit." 35

This Antinomianism crisis created a phobia which means to to associate any minister with it would seriously jeopardise his reputation. This is the reason why Chauncy associated the New Lights with the Hutchinson controversy, to paint the Awakening as another Antinomianism at play. Smart applauds Chauncy's shrewd tactics in playing this card, "His theological perspective may have tended towards Arminianism, but the more culpable position form the common past was the ever-present threat of Antinomianism. ${ }^{36}$ Apparently Chauncy was aware that both Edwards and Cotton were not Antinomians; both of them from Chauncy's perspective, "apparently sounded like and associated with Antinomians. ${ }^{37}$ The association itself was enough to bring damage.

\section{Enthusiasm}

The New Lights sometimes were labelled as the enthusiasts because of their emphasis on emotionalism. Those kind of emotionalism were gradually being seen in more places from mid-1741 onwards. Chauncy

$34 \quad$ Ibid., 183.

35 Smart, Jonathan Edwards's Apologetic, 185-186.

36 Ibid., 184.

37 Smart, 187. 
himself observed this had spread even further "none of which effects seem to have been accidental, nor yet peculiar to some particular places or constitutions; but have been common all over the land." 38 Furthermore their manner of enthusiastic preaching were deemed "more fit for the stage than the sacred desk" and their purpose was "to astonish the imagination rather than possess the mind of a reasonable conviction of these awful truths of God." 39 Smart concluded, "It was the mind rather than the imagination that was the proper target for the Spirit in Chauncy's opinion." 40

Edwards initially concede such extraordinary circumstances by offering explanation, the people experienced "a sense of sin and wrath, and having their strength taken away, and their minds extraordinarily transported with light, love and comfort" 41 which he had witnessed the effect firsthand in his delivery of Sinners in the Hands of an Angry God sermon in Enfield. However, Edwards made clear that those appearances was not proof of any saving work of the Spirit and thus should not be encouraged or acknowledged as the essential part of the Spirit's work.

Without question, the rise of the fanatical element coincided with the decline of the spiritual power of the Awakening. Those who spoke most loudly of being led by the Spirit were the very persons responsible for quenching the Spirit's work.42 For Edwards the turning point in the revival came when the New Lights failed to guard against excesses. Edwards ever gave his opinion about Davenport "He does more towards giving Satan and other opposers an advantage against the work than any one person." 43 The revival's worst enemies were found among its most zealous friends.

\footnotetext{
38 Smart, Jonathan Edwards's Apologetic, 77.

39 Chauncy, Seasonable Thoughts, 109.

40 Smart, Jonathan Edwards's Apologetic, 202.

41 Ibid., 217.

42 Ibid., 227.

43 Murray, Jonathan Edwards, 225.
} 


\section{Davenport's Legacy}

A year later after Davenport erratic incidents, and after continuing ministration from the New Light moderates and Edwards role in confronting him, Davenport published an apology entitled Confessions and Retractations in 1744. He confessed that he had been led by a "false spirit" in his excesses, which includes his book burning incidents. By 1745 Davenport was forgotten but one might question whether Davenport had a lasting significance. Brockway in his article wrote, "In some ways he did, Davenport was the archetypal American revivalist." 44 When Davenport was compared with his contemporaries, "Edwards was solemn in the pulpit; Whitefield, despite his persuasive oratorical powers, preferred the Anglican service... But Davenport was the exhorter of the classical camp meeting type." 45 He draw a similarity between the current preaching of camp meeting with Davenport's style, "He preached spontaneously without notes or preparation; prayed as the spirit moved. His sermons, if they could be called that, had little or no doctrinal content, were fervent appeals to repentance." 46 Further consequences in the long term can be drawn that "Davenport's was the pattern later followed in the Nazarene, Holiness, and Pentecostal sects, the forms of Protestant Christianity most distinguished for emotionalism." 47 Brockway then asked a question "Was he the progenitor of this type of evangelism?" which he answered "Once again, indirectly he was." ${ }^{48}$

Both Chauncy and Edwards called for public and outward test of ordinary means of grace such as good works as manifestation of the fruits of the spirits to counter Davenport's subjective emotional feeling or experience

44 Robert W. Brockway, "Significance of James Davenport in the Great Awakening," The Journal of Religious Thought, 24 no. 2 (1967 - 1968): 93.

45 Ibid.

46 Ibid.

47 Ibid.

48 Ibid. 
as a proof of assurance of salvation. But Davenport's emphasis on inner conversion experience as the ultimate test did not stop at him. Though not directly related, some characteristics emphasised by Davenport Individualism, inner emotional feeling, shallow doctrinal content -were shared by the Second Great Awakening and subsequent "awakenings" Pentacostalism and Charismatic movements.

\section{The Dangerous Tendencies of the Opponent Old Lights}

The Old Lights represented by Chauncy were seen as the guardians of the stability and order of the society against the chaos and disorders brought by the Great Awakening.

Smart concluding from Goen's work about the source of difference between Edwards and Chauncy, "their different views of human nature and psychology affected their demonology and pneumatological understanding, which led to debate over the nature of true religion itself." 49 But in the innermost, the differences were much deeper then their difference in language, view of psychology. "Disorder, not Jonathan Edwards of Edwards psychology, was the main target of Chauncy's criticism of the Great Awakening"50 Griffin offered the startling conclusion. What motivates him the most was not theological concern but rather "the Awakening's threat to his entrenched clericalism and membership of Boston's Standing Order."51 During the continued debate between the Radical New Lights and the Old Lights, towards the end of the Awakening era, the Old Lights were at the offensive side and the Radicals at the defensive corner. Through his cold and rationalistic emphasis, Chauncy led the Old Light to two dangerous tendencies:

\footnotetext{
49 Smart, Jonathan Edwards' Apologetic, 235.

50 Edward M. Griffin, Old Brick, Charles Chauncy of Boston, 1705-1787 (Minneapolis: University of Minnesota Press, 1980), 88.

51 Smart, Jonathan Edwards's Apologetic, 235.
} 


\section{No. 1: Rationalistic Theology}

The main underlying differences between Edwards and Chauncy among many other things, according to Marsden was, "a crucial philosophical issue" more than a theological issue.52 That issue in Chauncy's words himself was, "The plain truth is an enlightened mind, and not raised affections, ought always be the guide of those who call themselves men; and this, in the affairs of religion, as well as other things." 53 Edwards and Chauncy's view of affections could not be more different. Chauncy's understanding of affections can be traced from ancient Greek philosophy, which affections were perceived as intemperate emotions or passions, which needed to be restrained by the higher faculty of reason. Edwards explicitly rejected Chauncy's low view of affections as based "on philosophy rather than Scripture." 54 Edwards later in his Religious Affections laid out clearly his high view of affections, "True religion in great part, consists in holy affections." ${ }^{55}$ Edwards defended that affections were not inferior passions or emotional outburst as understood by Chauncy but were deeply related to the will that directed the whole person. This will or inclinations, sometimes referred as someone's "heart". For Edwards affections were not peripheral things but it was the central component in true religion.

Chauncy's objection to the Awakening was that they gave too much stress on the importance of emotions as the basis of faith, thus "overemphasizing the irrational part of religious life." 56 Chauncy swayed to the other extreme: against all kind of supranatural. Chauncy was denying that the revivals required supernatural explanations of any sort. He then laid

52 Marsden. Jonathan Edwards: A Life, 281.

53 Chauncy, Seasonable Thoughts, 327.

54 Marsden. Jonathan Edwards: A Life, 281.

55 Edwards, Religious Affections, 23.

56 Accessed Sept 4, 2015, http://www.encyclopedia.com/topic/Charles_Chauncy.aspx 
out his case in his Seasonable Thoughts. In it, he demanded a revival of religion without extravagance, strange effects, or mystery.

The direction which Chauncy was to urge, Edwards rightly saw would lead to a mere formal Christianity, akin to the rationalism which was already influential in eighteenth-century Deism. However, unlike some believers in the power of reason, Chauncy never drifted away from Christianity toward deism. ${ }^{57}$ He drifted away into something else, which would be discussed next.

\section{No. 2: Liberalism, Arminianism, Unitarianism, \& Universalism}

In his book, Old Brick: Charles Chauncy of Boston, Griffin presents a thumbnail summary of Chauncy's life and work which Chauncy played a major role in the rise of Enlightenment, in the rise of the Enlightenment, in the growth of "liberal Protestantism," social changes in Boston, and in the development of Unitarianism among other things. ${ }^{58}$ One Encyclopedia even state Chauncy's most radical contribution to American religion was in his thinking about salvation: Unitarianism. ${ }^{59}$

Because of his renouncement of the orthodox Calvinism and his bent toward Universalism, Chauncy was remembered in history as "an important figure in the beginnings of Unitarianism, liberalism, and natural religion in the visible church". ${ }^{60}$ How did he progress to that end started when he reacted against the orthodox Calvinism doctrine such as the doctrine of Christ's divinity, original sin and emphasised instead the innate goodness of human nature. ${ }^{61}$

\footnotetext{
57 Accessed Sept. 4, 2015, http://www.encyclopedia.com/topic/Charles_Chauncy.aspx.

58 Griffin, Old Brick, viii.

59 Accessed Sept. 4, 2015, http://www.encyclopedia.com/topic/Charles_Chauncy.aspx.

60 Smart, Jonathan Edwards's Apologetic, 301.

61 Marsden noted the shift of Chauncy's stance took seven years - Marsden. Jonathan Edwards: A Life, 436.
} 
While Awakening preachings pointed up the need of new birth or of experiential religion in order to reverse their inherited sinful nature, Chauncy did not see the need of conversion because he did not believe in this inherited sinful nature.62 Furthermore, Chauncy insisted that "no one needed to be converted because everyone would be saved -a position known as universalism, which was in keeping with his unitarianism, which maintained the oneness of the Godhead. ${ }^{63}$ His other conclusion was his objection against the propitiatory or substitutionary nature of Christ's death - Christ did not substitute sinners in their place to receive the punishment of their sins from God's wrath. As early as 1762 Chauncy began to explored the doctrine of universal salvation - that Christ's death had saved all humans, not only an elect few, as traditional Calvinists believed. Of course that was extremely radical idea for the time, and he explored it cautiously, and he only made public his view innear the end of his life anonymously in 1784.64 Chauncy argued in Salvation for All Men, his published sermon, the doctrine of universal salvation, by piling text upon text that alluded to the universality of salvation while ignoring those that discuss divine election. ${ }^{65}$

The fact that the Unitarians trace their roots to Chauncy and the Old Lights are claimed by Robinson when he writes, "The history of Unitarianism begins therefore with only one faction of opposers of the revival centred principally in the Boston Congregational Churches, those churches of the Standing Order that were originally founded in the Puritans migrations." ${ }^{66}$ In Chauncy, we can see a drift from one end of a pendulum

\footnotetext{
62 Accessed Sept. 15, 2015,

http://static1.squarespace.com/static/5096b7d0e4b09e8938274e06/t/52264736e4b032f22536a979/1 378240310042/Gray_Unitarians.pdf

63 Ibid.

64 Accessed Sept. 4, 2015, http://www.encyclopedia.com/topic/Charles_Chauncy.aspx.

65 Lambert, Inventing The "Great Awakening", 210.

66 David Robinson, The Unitarians and the Universalists (Westport: Greenwood Heinemann, 1985), 10.
} 
as a defender of Puritan orthodoxy to the other end as the pioneer of Unitarianism.

\section{Edwards' Answer: Emphasis on Religious Affections}

Jonathan Edwards Treatise Concerning the Religious Affections represents his "best and maturest conclusions" on the Awakening theme. ${ }^{67}$ Contemporary writers are very generous in their praises to it. It is, in the opinion of many, the most important and accurate analysis of religious experience ever written. ${ }^{68}$ Others have considered this to be the most penetrating guide to spiritual discernment ever written. ${ }^{69}$ Another token of Edwards importance is acknowledged inside the three-volume Encyclopedia of the American Religious Experience, which contains far more references to Edwards than to any other single figure ${ }^{70}$, partly because of his emphasis on affections.

On the surface Religious Affections were a treatise to answer the radicals' excesses and the opponents' attacks. However, according to Edwards there were two issues on higher stake when he wrote the first sentence in his preface "There is no question whatsoever that is of greater importance mankind and that it more concerns every individual person to be resolved."71 Those two questions were the two main points of the book:

1. What are the distinguishing qualification of those that are in favour with God, and entitled to his eternal rewards? or in short, what is the nature of true religion.

\footnotetext{
67 Alexander Smylie, "Introduction," The Religious Affections (Edinburgh: Banner of Truth Trust, 1986), 12.

68 Samuel Storms, Signs of the Spirit: An Interpretation of Jonathan Edwards' Religious Affections (Wheaton: Crossway, 2007), 21.

69 McDermott, Understanding Jonathan Edwards, 6.

70 Ibid., 4.

71 Jonathan Edwards, The Works of Jonathan Edwards, ed. John E. Smith. (New Haven: Yale University Press, 1959), 84. Afterwards any quotes from this source will be written as WJE.
} 
2. Wherein do lie the distinguishing notes of that virtue and holiness that is acceptable in the sight of God? or simply, what is the criteria to discern true and false religion, authentic or counterfeit piety ${ }^{72}$

\section{True Religion}

Edwards answer to the first question, contra Chauncy, was that "true religion, in great part, consist in holy affections." 73 To the second questions, he devoted more than three hundred pages to list down a detailed twelve negative signs and twelve positive signs of true religious affections. Harry $S$. Stout, Yale philosopher who were tasked to write introduction to Yale's edition of Religious Affections, observed that the whole of Edwards thought can be considered as "one magnificent answer" to the question, "What is true religion?"74

Edwards identified two exercises of true religion, namely love to Christ and joy in Christ. The love of Christ enable true Christians to endure "great sufferings, to renounce all that was dear" to them and their joy in Christ were greater then sheer sufferings, which enabled them to "suffer it with cheerfulness."75 Love to Christ rests upon a spiritual sight, since the object of love is unseen with ordinary eyes, and joy in Christ is the fruit of faith. ${ }^{76}$ And from these two principle, the main conclusion Edwards raised was this: "True religion, in great part, consist in Holy Affections."77

\section{Discernment}

Edwards set his eyes on both the opponent Old Lights and also the radical New Lights by maintaining a middle stance. His difficulties was to

\footnotetext{
72 WJE, 2:84.

73 Ibid., 2:95.

74 John E. Smith, “Editor's Introduction," WJE 2:2.

75 Ibid., 2:94-95.

76 Ibid., 2:12.

77 Ibid., 2:95.
} 
be caught in between rejoicing in "the glorious extraordinary appearances" and opposing "the evil and pernicious tendency". ${ }^{78}$ John E. Smith noted that, "he was quite literally caught between two fires in his attempt to defend, on the one hand, the importance of the affections and, on the other, his insistence on testing their genuineness."79 He then explained that one should not wonder too much as if this mixed work was something very unusual. It was because "much false religion should prevail, at a time of great reviving of true religion" which also could be seen in the times of king Josiah, of John the Baptist, and even of Jesus, including in the great sixteenth century reformation era. ${ }^{80}$ This mixture work were to be found along the church's history is consistent to Augustine's principle that the church is a corpus per mixtum (a mixed body). ${ }^{81}$

This mixture work if not discerned and distinguished would become Satan's most effective tool to disrupt and attack the Kingdom of God, "much more than by all the persecutions of both jews and heathens." 82 Satan's strategy was to drive both the supporters and the opposers of Awakening to great extremes, "till the right path in the middle is almost wholly neglected." 83 Smart concludes the reason Chauncy rejected the Awakening as valid work of the Spirit because he was unable to accept that "revival was a mixed work."

The fact someone having affections that are religious in nature does not necessarily mean that the source of those affections must come from the Holy Spirit. The counterfeit affections can flow from "self-interest or even demonic deception." ${ }^{84}$ Edwards was aware of the potential of deceptions,

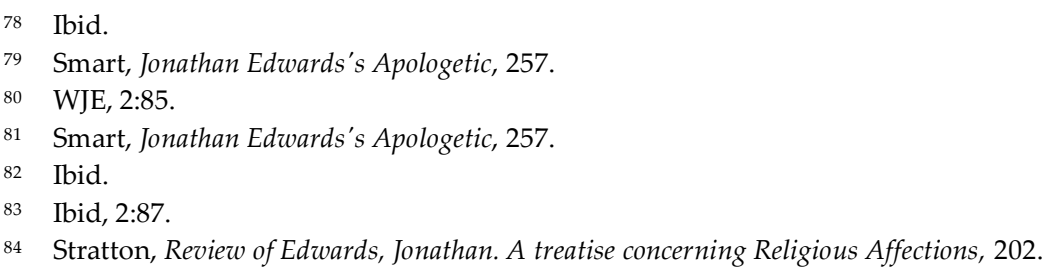


thus he devoted his second part in the treatise to list down feelings, thoughts, and behaviours that are "no certain signs that religious affections are truly gracious" 85 . He boldly listed many of the signs exhibited in the Great Awakening, declaring that it is not necessarily an indication that someone has actually been saved just because they experience religious affections that (1) are intense, (2) produce bodily effects, (3) cause fluent, fervent and/or abundant religious talk, (4) are not excited by the subject themselves, (5) bring Scripture to mind in a remarkable manner, (6) produce the appearance of love for God and others, (7) are many in number, (8) follow in a certain order, 9) produce much time in religious activities, (10) dispose people to sing praise to God, (11) make people exceedingly confident of God's leading, or (12) produce affections in others when shared. ${ }^{86}$

Smart distills the whole treatise and came to conclusion that Edwards laboured to vindicate the Awakening as a true work of the Spirit by addressing three main areas, "first, the centrality of religious affections in true religion; second, the nature of Christian experience; and third, the Awakening's controversial issue of obtaining an assurance of salvation in light of the appearance of New Light Antinomianism." 87 These divisions will be used for this paper subsequent headings as we analyse Edward's apologetics there.

\section{The Centrality of Affections}

Chauncy earlier in his Seasonable Thoughts ever questioned the emphasis of affections in the Awakenings, "The plain truth is an enlightened

\footnotetext{
85 WJE (part II), 2:126-190.

86 Stratton, Review of Edwards, Jonathan. A treatise concerning Religious Affections, 202.

I use Stratton's summary instead of Edwards's original, as Stratton's shorter and modern adaptation gets the essence without diluting the meaning.

87 Smart, Jonathan Edwards's Apologetic, 259.
} 
mind, and not raised affections, ought to be the guide... in the affairs of religion." ${ }^{88}$ Edwards exaltation of the affections was never at the expense of reason. By stating the centrality of affections, Edwards argued that his emphasis on the centrality of religious affections was not simply philosophical outworking, but it was testified by Scripture itself, "the Holy Scripture do everywhere place religion very much in the affections; such as fear, hope, love, hatred, desire, joy, sorrow, gratitude, compassion and zeal." 89 Edwards gave examples of people of deep feeling in the bible includes David known as a man after God's own heart, who wrote several stirring and emotional psalms; Paul wrote of his deep feelings and affectionate love towards his congregations; Jesus expressed himself emotionally several times as well.

Edwards found strong bases to argue his centrality of affections thesis, not only from the scripture, but also on God's nature. "What God's Spirit accomplished by a larger measure of His presence was a greater manifestation of Himself", Smart then continues to explained the consequence "believers participated in the divine nature primarily through the religious affections that the Spirit produced within them."90

Edwards also link his centrality of affections with the work of Holy Spirit. Edwards earlier had argued for "the identification of the fruits of the Spirit and the affections." ${ }^{\prime 91}$ These fruits of the Spirit as noted in the bible "the peace of God, the joy of believing, the light of knowledge of God's glory in Christ, the love of God dwelling in the heart"92 are the sure evidence of the work by the divine Spirit. To pray for the coming of the Spirit is to demand for the affections. Thus it is inconceivable to think of a people

\footnotetext{
88 Chauncy, Seasonable Thoughts, 326-327.

89 WJE, 2:102.

90 Smart, Jonathan Edwards's Apologetic, 261. Smart summarize this idea from Sang Hyun Lee

"God's relation to the World," Princeton Companion, ed. Lee: 59.

91 WJE 2:7.

92 Ibid.
} 
waiting upon the Spirit but had no religious affections, for "affections must be present if the Spirit is present at all." 93

First of all, it is important to set the definition precisely because Chauncy tend to understand affections as passions or emotions. Not all will or inclination can be called affections however "it differs nothing at all from the will and inclination ... only in the degree and manner of exercise," for instance affections of love is a vigorous inclination of the soul toward something in high degree. Thus affections are "the strongest motivations of the human self, ultimately determining what a person is and does"94 Or in another perspective, "the strongest inclination of the heart and are manifested in thinking, feeling, and acting." 95

To further understand what Edwards meant by affections, it is helpful to read his distinction between affections and passions.Edwards thoughts of affections as more extensive than passion for it covers for all vigorous lively actings of the wills or inclination; while passion only those who are more sudden and that overpower the mind to make the person lose control. ${ }^{96}$ In contrast, affections are "active reflexes by a person to another person or object that are evoked by an idea or understanding of the nature of what affect us." 97 The things that evoked our affections are the divine excellency and glory of God in themselves, Edwards explained in his second positive sign of authentic affections. Edwards elaborated further by saying those affections that are truly holy are primarily founded on the loveliness of the moral excellency of divine things. Or to put it differently, a love for divine things for the beauty and sweetness of their moral excellency is the first beginning and spring of all holy affections.

93 Ibid.

94 Smart, Jonathan Edwards's Apologetic, 265.

95 Ibid.

96 WJE, 2:98.

97 Smart, Jonathan Edwards's Apologetic, 264. 
Edwards therefore devotes the third section of Religious Affections (fully $70 \%$ of the work in length) to "showing what are the distinguishing signs of truly gracious and holy affections". Religious affections are truly gracious only when (1) they arise from a divine operation upon the heart, (2) their object is the inherent beauty of divine things, (3) they are founded on the moral excellency of holiness, (4) they arise from divine illumination, (5) they are attended with the certainty of divine things, (6) they are marked by evangelical humility, (7) they are attended with a change of nature, (8) they promote the character of Jesus, (9) they are attended by a tenderness of spirit, (10) they are not over- balanced, but have a beauty of symmetry, (11) they increase rather than de- crease appetite for spiritual attainment, and (12) they have their exercise and fruit in Christian practice. ${ }^{98}$

\section{Nature of Experience}

Chauncy reacted against the emotionalism and enthusiasm of the Awakening, believing true religion had to be sober, calm and reasonable. He taught that the Spirit warmed the mind at a gradual rate whereas a sudden outburst of terror were not to be attributed to the Spirit's work. ${ }^{99}$ The Awakening preachers' emphasis on terror, on the other hand, may have been a major reason for Chauncy's later emphasis on God's benevolence and subsequent incipient universalism in 1752.100 His hostility against experiential religion and use of terror moved him to the other pendulum.

Edwards were very critical of people who use their past intense or spectacular conversion experience as their foundation of assurance (just like many modern evangelicals who based their assurance of salvation on their experience raising their hands and walked the aisles on a particular revival meeting). Those who counts on their "past conversion moment" as a mark of

98 Stratton, Review of Edwards, Jonathan. A treatise concerning Religious Affections, 203.

99 Smart, Jonathan Edwards's Apologetic, 203.

100 Ibid., 199n172. 
their true identity and spirituality according to Edwards, were on a shaky ground for "a truly gracious assurance could never be grounded on the identification of a particular conversion moment."101

What differentiate Edwards and Chauncy in terms of their evaluation of experience was that Edwards did not condemn all high affections blindly, just like Chauncy, who were so prejudiced against it and immediately judge all high affections as delutional. His criticism and negative evaluation Edwards heaped on the high affections were tempered by his writing of positive evaluation three times longer. Edwards wrote a parallel effect "if true religion in the hearts of men, be raised to a great height, divine and holy affections will be raised to a great height." ${ }^{102}$ The biblical texts not only speaks of great and high affections but also commands Christians to "exercise very high affections" such as in the first and greatest commandment: Thou shalt love the Lord thy God, with all thy heart, with all thy soul, with all thy mind, and with all thy strength. Storms sums up nicely the dialectic tension, "whereas the existence of heightened affections does not itself prove the reality of one's religious confession, the absence of affection certainly proves its falsity." ${ }^{103}$

\section{Assurance of Salvation}

There is a tendency on the one hand to think there is no such thing as "a full and absolute assurance of hope" and another to delude themselves of having assurance without true basis of saving faith. The latter were prevalent in the circle of the radical New Lights. In the midst of both erroneous options, Edwards proved from the scripture that shows it is "God's design to make ample provision for the saints having an assured

\footnotetext{
101 Chamberlain, Self-Deception, 549.

102 WJE, 2:127.

103 Storms, Signs of the Spirit, 59.
} 
hope of eternal life, while living here upon earth."104 It is definitive that God revealed and gave his special favour to Noah, Noah, Abraham, Isaac, Jacob, Moses, Daniel, and others. Jesus in New Testament also showed his assuring promise not only to his disciples but also to the robber next to his cross that they would share his eternal glory.

Edwards was very cautious to tread the line of "assurance" confirming what Ava Chamberlain analyzed, "the point at which the revivalists were most vulnerable to the influences of self-deception was in their understanding of the means by which the justified sinner acquired assurance of salvation." 105 Edwards wrote of his eleventh signs of nothing as "merely having deep and profound assurance that one is saved proved nothing about the authenticity of one's faith."106 The irony was "some hypocrites are a great deal more confident than many saints" 107 as claimed by Solomon Stoddard. We should not be too surprised because if we know deeply about the human heart. The unregenerate heart was under the dominion of "blindness and deceit, self-flattery, self-exaltation and selfconfidence"108 which lead to a false comfort. The hypocrites never put their hope into question because "the devil don't assault the hope of the hypocrite, as he does the hope of a true saint...the devil never disturbing it, nor attempting to disturb it."109 On the other hands, the regenerate believers embrace the assurance of salvation with humility and caution, always aware of their own blindness, and the deceitfulness of their own heart before God.

Doubting one's faith is not always a lack of it, instead sometimes it brings good out of it. "Nor is it at all to be lamented that persons doubt of their state in such circumstances;" Edwards wrote, "but on the contrary, 'tis

\footnotetext{
104 WJE, 2:169.

105 Chamberlain, Self-Deception, 543.

106 Storms, Signs of the Spirit, 70.

107 Solomon Stoddard, The Way to Know Sincerity and Hypocrisy (Boston, 1719), 128.

108 WJE, 2:172.

109 WJE, 2:172.
} 
desirable and every way best that they should."110 It is a good sign because the hypocrites never doubt their faith. The believer's doubt is not a failure of their faith, but in fact it can be God's mercy for them that they will always cling their hope on God not on their fragile faith. But for those people who had constant fear of their eternal destiny, Edwards comforted them from the verse from John 4:18, "There is no fear in love, but perfect love casts out fear ... Fear is cast out by the Spirit of God, no other way than by the prevailing of love" reminding them only love can overcome their fear. "These two opposite principles of lust and holy love, bring hope and fear into the hearts of God's children, in proportion as they prevail."111

Edwards as a Puritans heir inherited Puritans' legacy of selfexamination in their spirituality. However, after the episode of two Awakenings with the excesses, Edwards cautioned against over-reliance upon self-examination as the primary means to know their spiritual state. Westminster Larger Catechism question 81 pointed out that assurance may "be weakened and intermitted, through manifold distempers, sins, temptations, and desertions; yet they are never left without such a presence and support of the Spirit of God as keeps them from sinking into utter despair."112 Since inner experience were unreliable, a firmer ground should be sought rather than self-examination: "Although self-examination be a duty of great use and importance, and by no means to be neglected; yet it is not the principal means, ... Assurance is not to be obtained so much by selfexamination, as by action." 113 Then what Edwards suggested his people to do? "Tis not God's design that men should obtain assurance in any other way, than by mortifying corruption, and increasing in grace, and obtaining

\footnotetext{
110 WJE, 2:179.

111 WJE, 2:180.

112 The Confession of Faith Together with the Larger Catechism and the Shorter Catechism with the Scriptural Proofs (Atlanta:Christian Education and Publications, 1990), 45-46.

113 WJE, 2:195.
} 
the lively exercises of it."114 For Edwards, experience without practice was worse than nothing ${ }^{115}$ while practice without inward experience was akin to hypocrisy.

Edwards in his twelfth signs of religious affections, made a strong case for Christian practice, against the charge of antinomianism that Old Lights laid upon the New Lights. He said not only "Christian practice or a holy life is a great and distinguishing sign of true and saving grace" but it is also "the chief of all the signs of grace" to judge the sincerity of godliness. ${ }^{116}$ While inward conversion experience was susceptible to self-deception, Christian godly life is "the most reliable sign to read the Spirit's work in the affections of the heart."117 But this sanctification process was not to be viewed as another "once-for-all experience but as an increase of assurance to be sought through ongoing communion with God."118

Gracious affections always bear fruits in holiness. It will always flow without a doubt.Isn't is reasonable to expect water-spring to gush the stream out? and fire to burn? Gracious affections will always result in godly practice. An objection often raised that Edwards moved into the direction of legalism by placing so much emphasis on godly practice. The objection fell into absurdity because it missed the position of good works, as "good works are a threat to divine grace only if they are the price we pay to gain it, not if they are the sign of its presence."119

\footnotetext{
114 Ibid.

115 WJE, 2:452.

116 WJE, 2:406.

117 Smart, Jonathan Edwards's Apologetic, 286.

118 Ibid.

119 Storms, Signs of the Spirit, 151.
} 


\section{Edwards Legacy}

Earlier it has been described the dangerous tendencies both the radical New Lights and the opponents Old Lights will lead to extremes positions. Some characteristics emphasised by Davenport and other radical New Lights were shared by the Second Second Great Awakening and subsequent "awakenings" such as Pentacostalism and Charismatic movements in the twenty-first century. Whereas Chauncy and Old Lights tended to gravitate towards rationalistic theology or deviated from Christian orthodoxy such as Unitarianism and Universalism. Mark A. Noll's book The Rise of Evangelicalism: the Age of Edwards, Whitefield and the Wesleys has a telling title, clearly attributing those four people as the main figures, who proved to be foundational in the development of Evangelicalism movement. Noll claimed in his book, the Great Awakening were "the beginnings of the evangelicalism." 120 The expansive and ever-diversifying family tree of present-day evangelicalism ${ }^{121}$

Noll review of the modern scandal of the evangelical mind is that "there is not much of an evangelical mind ... American evangelicals are not exemplary for their thinking." 122 What an irony! For the career of Jonathan Edwards shows us how fruitful it can be to love the Lord with the whole mind. ... It is not simply advantageous to love the Lord with the mind; it is also good, sweet, holy, beautiful, and honouring to God. ${ }^{123}$ Edwards was responsible for the most God-centered as well as the most intellectually subtle reasoning in all of American evangelical history.

Yet, Edwards was also a promoter of the revival that pushed American evangelicalism in a direction that made it unable or unwilling to benefit from his own intellectual work. As a result, evangelicalism's most

\footnotetext{
120 Noll, The Rise of Evangelicalism, 18.

121 Ibid., 19.

122 Mark A. Noll, The Scandal of the Evangelical Mind (Grand Rapids: Eerdmans, 1994), 3.

123 Ibid., 79-80.
} 
discriminating thinker is best known for one fairly untypical sermon, Sinners in the Hands of an Angry God. Moreover, in the great recovery of Edwards reputation that has taken place in the last generation, the lead was taken by secular scholars for secular purposes, while evangelicals have played only a secondary role in the recovery. The riches of his thought remain virtually unknown among the hordes of evangelicals who are his religious descendants.

What was passed down in history by Edwards were not what Edwards himself would have expected. In later generations, American revivalists were more likely to follow Edwards in appealing for the new birth than were American theologians in defending the broadly Calvinistic themes so central to his concern. ${ }^{124}$ This might be surprising for Edwards for he saw himself more of a pastor and a thinker than as a revivalist.

\section{Edwards Contribution in the Revival Tradition}

Revival tradition throughout the history have shown two tendencies. One is total openness toall kind of spectacular phenomena that arouse people's interest in religion and call it revival. The other is total antipathy toward revival for what the church need is steady and progressive reformation rather than spurting revivals. The valuable contribution of Edwards is his stance towards revival that combine "openness to new kinds and degrees of spiritual experience with caution in appraising and assessing all spiritual phenomena." 125 In this part, we would see Edwards contribution in revival tradition through out the history.

Although Edwards was credited to be foundational in the development of evangelicalism, his foundation did not last very long. American evangelicals by 1800 would everywhere champion the naturalism,

\footnotetext{
124 Mark A. Noll, A History of Christianity in the United States and Canada (Grand Rapids: Eerdmans, 1992), 97.

125 McClymond, The Theology of Jonathan Edwards, 675.
} 
the optimism, and the scientific rationality. ${ }^{126}$ The next figure who would be prominent to carry another major awakening was Charles G. Finney (17921875). Finney associated himself with Edwards but on the basis of his own interpretation and adaptation, which were proved to be a departure instead of continuation of Edwards' legacy.

His revivals shifted the reformation orthodoxy to arminian flavour, where human response is more important than God's initiative, for example in his view that "sinner's own unwillingness, not the sinner's inability was the cause of spiritual emptiness." 127 The middle view that Edwards tried to built in response to both extremes responses to revival: the inner experience must be confirmed by public tests - overt godliness or holy life, was to be thrown out of balance once again in Finney's time. In the second Great Awakening, Finney moved the balance to the other end once more; he "made the conversion experience in revivals the test of the Spirit's work and the assurance of God's love." 128

Next, the transitions period of the late 1800s and early 1900s brought a wind of change which overthrow Edwards legacy to the sidewalk. The dominant category of thought has shifted from Puritanism to Romanticism, which the concept of immanence rather than transcendence was the rule the day. During these period, conversion and revivals were viewed through "a moralistic and naturalistic lens... Conversion was tantamount to moral resolution and revival was a psychological phenomenon."129 Edwards had no place in such atmosphere. In the beginning of the twentieth century, Pentecostal movement emerged as the next powerful spiritual awakening and culminated in the Azusa street revival in Los Angeles during 1906-1908. This emerging movement displayed both old manifestation seen in the

\footnotetext{
126 Noll, The Scandal of the Evangelical Mind, 87.

127 Ibid.

128 Smylie, Testing the Spirits in the American Context, 36.

129 McClymond, The Theology of Jonathan Edwards, 688.
} 
previous centuries revivals - emotionalism, bodily affection and visions and also new manifestation not seen before - speaking in tongues and divine healing.

Edwards resurgence only appears before the closing of the twentieth century, "in the discussion ofthe 1960-1970s Charismatic Renewal and Jesus Movement, the 1980s Vineyard Church revivals, and the 1990s Toronto Blessing." 130 Charismatic Movement of Toronto Blessing was the most controversial of all, attracted numerous controversies in which both revival proponents and opponents "appealed to the writings of Jonathan Edwards in support of their view." 131 The proponents also accused the critics were "excessively intellectualistic" and the critics did not interview the people affected by the Toronto Blessing to get first-hand facts themselves. More or less, their debate in a way can be seen like another repetition of the Great Awakening's debate three centuries ago. Edwards middle stance was prone to be read in two ways to lend support by both opposite camps.

A well known quote "Those who cannot remember the past are condemned to repeat it" is a good reminder for Christians in the current age to remember, treasure and learn from the richheritage of Edwards in order not to repeat the same mistakes. The bad news is certain extremes and erroneous practices cannot be avoided and sure to continue. But the good news is the fact that Edwards writings were so extensively cited, analysed and argued during the last twenty years as an indication that this theology of revival continues to be of importance today. ${ }^{132}$

\footnotetext{
$130 \quad$ Ibid., 691.

131 Ibid.

132 Ibid., 694.
} 